\title{
The Linguistic Appraisal of Foul Language in Selected Yorùbá Video Films
}

\author{
Tèmítọ́pẹ́ Olúmúyìwá* \\ Adekunle Ajasin University \\ Akùngbá-Akókó, Nigeria
}

Received 27.12.2015, received in revised form 10.01.2016, accepted 30.01.2016

\begin{abstract}
Language is so subtle and complicated human phenomenon that it is used in communication for informative, expressive and directives. The environment we live is largely verbal therefore; language serves expressive function when used in conversation to get individuals to be more effective, polite and in causing or easing social tensions. In order to create social tension, foul language is usually employed. Though, the structural patterns of foul language used in everyday interaction in Yorùbá society are similar to the ones used in Yorùbá video films. This assertion confirms the generally belief that movie is a reflection of the society. The use of foul language in Yorùbá video films has become a common feature to be ignored. The foul language examined in them in this study is divided into two: insults (èebú) and curses (èpè). The main thrust of this paper therefore, is to give a linguistic appraisal of the two types of foul language used in Yorùbá video films. The paper examines the socio-semantic implications of foul language as it is used in the video films and shows that insults are more frequently used than curses in the films. Also, the paper examines the grammatical analysis of foul language used in the selected video films and posits that while insults come in noun phrases and sentences, curses are delivered in verb phrases and sentences. The sentences used in both cases are one clause sentences which consist of NP subject and a predicate thereby making it easy to grasp.
\end{abstract}

Keywords: Yorùbá, video films, Noun Phrase, Verb Phrase, Insults (èébú), curses (èpè).

DOI: 10.17516/1997-1370-2016-9-2-294-309.

Research area: sociology, politology.

\section{Introduction}

Language is a familiar feature of human life that we tend to regard it as natural and simple. The mechanism of language can best be seen at work in a simple speech-situation where it is used to link meaning to expression in a given context, Finegan (2004:7). Copi (1953:35) observes that language serves expressive function whenever it is used to vent or communicate feelings, emotions or attitudes. Expression may be analyzed into two components. It is used either to evince the speaker's feelings or evoke certain feelings (positive or negative) on the part of the auditor. Of course it may do both. The choice of different expressions has to do with the speech context and the respective roles the interactants take on, McGregor (2009:157). In other words, to grasp the intended content of an expression, hearers must examine it in the light of its context, Finegan (2004:7). Fodor (1982:19) opines that language

(C) Siberian Federal University. All rights reserved

* Corresponding author E-mail address: oluolumuyiwa@gmail.com, tope.olumuyiwa@aaua.edu.ng 
should be viewed not as an abstract calculus but as tool, the proper characterization of a linguistic expression must include an account of how it is used and what it is used for.

The environment we live in is largely verbal. We spend most of our waking hours speaking words or responding passively or actively to the words we heard, Kluckhohn (1949:41). We talk to ourselves, family members, and friends and associates, partly to communicate to them and partly to persuade them, or to express ourselves. In the conversation, we use words, phrases, sentences to comfort and cajole ourselves in fantasy and daydream, to let off steam, to promote our purposes in dealing with others. At times, we build up verbal pictures of ourselves and our motives. We coax, argue, command, protest, incite, swear, invite, threaten, insult, bless and even curse. From the foregoing, we observe that language is an instrument for action. Primarily the social value of speech lies in getting individuals to be more effective, polite and or in causing or easing social tensions. In order to create social tension, we tend to use foul words, phrases and sentences.

Movie is a reflection of the society. They are based on life-related stories which are crafted around happenings or conflicts, Mgbejume (2006:36). In expressing the various disagreements in the film dialogue, foul language is always employed. We observe that Yorùbá scholars have paid little or no attention to the linguistic study of foul language. This inadequate attention informs the present study. Though the structural patterns of foul language examined in this study is similar to the ones used in everyday interaction in the Yorùbá society. However, we decided to focus on Yorùbá video films because the use of foul language has become a common feature to be ignored. Moreover, there is no known work on its grammatical analysis in Yorùbá and hence, the need for this study. The aim of the paper, therefore, is to examine the grammatical analysis of foul language in some selected Yorùbá video films. In doing this, we delve briefly into the socio-semantic implications of foul language in the selected films.

\section{The Data}

Language is a form of social behaviour. It is a product of a particular culture and it reflects the culture of the people and their view of the world. Since there is no written law which controls the use of language in Yorùbá society, people often do not understand the very concept of good language and bad language nowadays. In recent times, a Yorùbá movie channel on DStv ${ }^{1}$, African Magic channel 157 uses bleep tone to censor words that are considered highly inappropriate and unsuitable for broadcast in the films it shows to the viewers. At times, the bleeping may be so frequent that it may nearly disrupt the dialogue in the films. To most people, the inappropriate language is part of our culture. The bleeping noticed on this African Magic's channel, also arouses our curiosity to investigate into the structure and use of foul language in some selected Yorùbá video films. For this study, we selected randomly, more than thirty video films among the numerous produced between 1995 and 2015. These video films include Ti Olúwa Ni Ilẹ (1995), Bánkàrere (2012), İyàwó Ẹlẹ́nu Razor (2006), Teacher Oko (2013), Ėtekéte (2011), Ọko Màmá È (2012), İbéèrè (2012), Osas (2012), Abúlé Mecho (2012), Alakada (2009), Suzzy Mama (2013), Abẹrẹe (2013), Dókità Ige (2011), Jẹjệlóye (2012), Oko Obinrin (2011), Ilé Aláyọ (2012), Ináwó (2013), Ẹù Arúgbó (2013), Pélé Mọdinà (2013), Màmá Insurance (2012), Aìná Òrósùn (2010), Odídẹrẹ (2006), İbínú Orúnmilà (2013), Ilá Alásèpọ (2014), Tẹbẹlú (2014), Ợẹ Mẹta Wèrè kan (2014), Wazo (2014)and Omo Elẹmọọọó (2013). We collected the data by identifying foul language in the video films, transcribed them for 
easy analysis. Space constraints would not allow us to attach the data collected as appendix to this write-up. However, we would make use of ample examples as necessary.

\section{Foul Language in Yorùbá Video Films}

Almost everyone in Yorùbá society from preteens, teenagers and the elderly are quite familiar with the use of foul language. Its use is so known and common in the speech of people that it is now becoming regular language in our daily conversations. Foul language is seen as indecent or obscene words and phrases. What is considered indecent or obscene varies from one culture to the other. Therefore, we want to add that foul language is a subclass of a language lexicon in a typical culture that is generally considered to be strongly impolite or offensive. In Yorùbá culture, insults, curses and vulgarism are typical examples of foul language.

The use of foul language in the society today seems to be on the increase. Words once thought to be unspeakable in the society now make a regular appearance in Yorùbá music (Adébọ̀álé \& Olúmúyìwá forthcoming), video films, television and even radio. The use of foul language in Yorùbá video films nowadays has to be the most confounding. In the past, before any film production is presented to the National Film and Video Censors Board (NFVCB), each producer of the motion Pictures in Nigeria must make sure his production does not run foul of paragraphs 13-15 of the code of ethics and production for film makers which forbids the use of vulgarity, obscene and profanity. Excerpts

\subsection{Vulgarity}

13.1. The treatment of low, disgusting, unpleasant thought not necessary evil subjects should always be guided by the dictates of good taste and a proper regard for the audience.
14.1. Obscenity in word, gesture, reference, song, joke, or by suggestion (even when likely to be understood only by part of the audience) is forbidden.

\subsection{Profanity}

15.1. Pointed profanity and every other profane or vulgar expression however used are forbidden. No approval by NFVCB shall be given to the use of 'swear words', abusive, sexual expressions and phrases in motion pictures

(Source: Ekwuazi et al. (2001:312))

In contemporary society, Nigerian Filmmakers (Nollywood) however flooded the film market with all manners of expletives and profanities as most of their video films run foul of the code of ethics for their production. This is attributed to many factors. First, most of the video films in the market do not pass through NFVCB before they are released into the market. Second, most video film producers are not honest in their dealings with NFVCB. The version of their video films they package to the NFVCB for censorship is not what is eventually released into the market. Third, the rating system of the video films allows people to say whatever they want in the movies. Therefore, one rarely finds a Yorùbá video film without the use of foul language in ordinary conversation. The foul language comes in the form of abusive words, phrases and in sentences. Foul language examined in this paper can be divided into two. They are insults (èébú) and curses (èpè).

\section{Insults}

Insults have been defined variously. They are considered a violation of the principles of politeness, (Leech 1983). Also, insults are seen as linguistic, paralinguistic of symbolic communication forms which are meant to cause mental pain, embarrassment or disgrace, (Agyekun, 2004). In similar vein, insults have been described as utterances with which speakers intend to offend their interlocutors by saying 
or doing something rude or insensitive that offends them, (Juker 2000, Fielder 2007). Babou (2014:112) opines that insult is a category of taboo which exists in many forms across cultures and languages used in downgrading, offensive and reprehensive manner to express the opposite of someone's value especially when it is intentional. Mateo and Yus (2013:92) believe that insulting is a social ritual learnt from childhood which is accompanies by a special kind of communicative exchange (verbal or nonverbal) usually involving a speaker who utters words with certain effects on addressee. We can deduce from the foregoing that insults are words, statements or actions that inflict or cause the emotional damage to someone.

The Yorùbá word for insult is èébú. Eébú (henceforth) is a word or statement or an action used (with the intention to be rude or scornful) to express one's emotion: hatred, aggression and anger to the people. The use of insults is not new. Throughout the centuries, human beings have exercised their highest powers of invention and wit of speaking ill of one another, Mcphee (1978:10). In Yorùbá society, the people are dynamic in expressing themselves. They don't hide their real thoughts, feelings and emotions behind fuzzy words and a mealy mouth. Yorùbá have in their lexicon, audacious words and phrases that can hurt more than body blows. Maybe that is why Olútóyè (1987:2) defines èébú among the Yorùbá people as speech used to ridicule people.

There are very few scholarly works on èébú in Yorùbá studies. Besides Olútóyè (1987) there is no other known works on èébú. Olútóyè's (1987) work describes different types of éébú, there after; it examines the place of èébú among Yorùbá oral genres. The study posits that éébú is one of the Yorùbá oral genres such as Ifá, İjálá, òwe, oriki etc. We are at variance with this position because èébú does not conform to all the corpus criteria universally used in the recognition of genres in oral literature i.e. content, stylistics features, mode of delivery, nature and training (if any), of the addresser, type of addressee, occasion... etc, (Yai (1975:601)). Besides, èébú is an act of invective which shows the speakers creative ability to easily invent insult. Apart from coming in words, which we shall examine later, it may also come in songs. As shown in the following song in the film: İyá Obámà.

1.

'Ọkọ wo ló kó wọn dé o by what means were they here,

Hèé hè, ọkọ wo ló kó wọn dé

Ará oko wọlú o,

Wọ́n ń tẹlẹ̀ bí ọ̣bọ;

Ọkọ wo ló kó wọn dé’ by what means were they here, the villagers are now in town, they are walking like (monkeys) fools, by what means were they here'

Innovation plays an important role in the creation of an insulting utterance, Fine (1981:94). Skilled insulters devise highly innovative expressions to launch their verbal missiles. Those who are witty in this act of verbal pyrotechnic are regarded as 'ẹlẹrẹ̣kẹ èébú' 'foul mouthed person' in Yorùbá society. Adéwálé Ẹlẹsọọ is a good example of such people in Yorùbá films.

\section{The Socio-Semantic implications of Foul language \\ in the selected Yorùbá video films}

Actions which are performed through the use of language are regarded as speech acts, Finegan (2004:296). The actions include greetings, giving complement, plead or flirt, to seek or supply information and insulting one another. Insults are culture-dependent speech acts. The principal components of speech acts include the utterance itself (locution), the intention of the speaker in making the utterance (illocution) and the effect of the act on the hearer (perlocution). In this section, we shall concern ourselves with the intentions of the speaker(s) to insult their interlocutors in Yorùbá films. 


\section{The Illocutionary Acts of Èébú}

In Yorùbá culture, èébú are not regarded as taboo as it is an integral part of their life. The use of èébú in Yorùbá video films could be seen as a carryover of the tradition of using èébú among the people. Most èébú used in Yorùbá video films are used in interpersonal relationship. People insulted and were insulted in these video films because they were in interpersonal relationship that permitted and encouraged the use of insults in verbal interaction. It is generally common in these video films that the speaker makes his intention to insult explicitly taunts and the interlocutor recognizes the insult. The addressee may feel insulted and reacts or decided not to react. Jucker (2000) and Gabriel (1998) share a similar view that insults have to produce cognitive effects that lead to a reaction. On the contrary, Mateo and Yus (2013:90) believe that a lack of reaction does not necessarily invalidate the insulting act. In Yorùbá video films, whenever a verbal attack is subtle and allusive especially between peers, it may not elicit any response from the addressee.

The Yorùbá video films however show a variety of intentions in the use of èebu among the people beyond that of offending, hurting and arousing the anger of the addressee. Such intentions include the following. First, in verbal dueling among the people, èébú are used in order to prove a superior skill in the use of Yorùbá language. Therefore, in Yorùbá video films, when there is trading of insults between addresser and the addressee in the presence of bystanders, the one that did not take insults would reply, either by saying "Mi ò kì $i$ șe omo lo sílé lo gba èsì wá." "I am not someone that needs to get home to reply you" or "Won ò gbé ẹnu mi fún alágbàfọ", "I don't need to take my mouth to the launder to reply you." Second, èébu are used in some cases in the video films to correct misdeeds in the addressee especially when they are subordinate to the addresser i.e. servants, younger ones. In this situation, the addressee may not react in most cases even when he feels insulted. Third, paradoxically, èébú are sometimes used in Yorùbá video films with the intention of flattering and showing admiration towards the addressee. For example, a housewife addressing her sister in-law as "iyá oko tí ò ko" "a miserly sister in-law" or "iyá ọko tí ò rọoộkán” "a sister in-law that is not civilized" At this instance, the addresser usually uses the right intonation, gesture or paralinguistic mechanism to avoid unwanted interpretations (Fine 1981:54). Fourth, èébú are also used in Yorùbá video films to describe the interlocutor. The description though in the negative, may describe either the physical features of the addressee or his behaviour in order to draw his attention or attention of others to his physical features or his infelicitous behaviour. It may even be used to show disapproval to such behaviour. Examples of such èébú are:

2.
i. Ẹlẹ́sẹ̀ wọgọowọgọ
'Someone with
curved legs'
ii. Òpònú Arígbìnínmáhe
iii. Ọdệ, o ò rẹ́nu ẹ̀, kộlikọli
iv. Etí ẹ dá dúró bí sọọọ̣ṣi oko
'A daft who do not utilize opportunities'
'Stupid person with bad mouth'
'His ear standing aloof like village church'

\section{Curses}

Over the centuries and in every human culture, a curse is an expressed wish that some form of calamities or misfortune will befall some other person(s) or entity. The calamities or misfortune intended by the curser may range from illness, bad luck, retrogression, harm to even death. In Yorùbá society, curse is known as èpè. Èpè (henceforth) is the opposite of İre 'blessing'. Èpè is variously used in Yorùbá culture. It is used to seek justice, revenge, or protection of property such as home, farm, land 
and other treasures. Just as we said concerning èébú there are few scholarly works on èpè in Yorùbá studies. The major scholarly work on it is òpè fèyìntìmí (2010). At a glance, the work looks exhaustive; however, a critical appraisal of it shows that there are few things left out in the work. First, the data used is restricted to Òyọ́ Yorùbá. Ơyọ́ Yorùbá can not be used as a yardstick for other Yorùbá people. Èpè that is peculiar to İjẹbú people is different from èpè peculiar to İjẹșà people. Therefore, there are èpè that are peculiar to different ethnic groups that constitute the Yorùbá nation. Second, the work believes that èpè is one of the Yorùbá oral genres which has three patterns: ibẹrẹ 'the beginning' ( $1^{\text {st }}$ stanza); àárín 'middle' ( $2^{\text {nd }}$ stanza) and ipari 'end' ( $3^{\text {rd }}$ stanza). To the present writer, èpè is not always poetic and static as the work appears to suggest. Besides, the different types of èpè mentioned in the work confirms our view that èpè is not poetic with stanzas as shown in the series of appendices containing copious data examined in the work.

Unlike èébú which is frequently used in everyday interaction among the Yorùbá people and in the selected Yorùbá video films, èpè is seldom used. This may be due to the fact that the people see èpè as objective reality with real power that is backed by magic, spell, supernatural or metaphysical forces. Depending on the curser, the use of èpè in the selected Yorùbá video films involves some level of ingenuity which depends on what make the curser lay a curse on another person or on himself. Linguistically, èpè is used in the selected Yorùbá video films as a vulgar epithet. In most of the Yorùbá video films selected, especially the comedy ones, èpè is used as a profane or obscene expression of anger, impatience, pride, disappointment, disgust, regret, or to prove a point or to show some level of honesty. Examples of such èpè include:
3. tèmí bàjẹ

ii. Mo dáran, bàbá yìi ba tèmi jẹ́ poo.

iii. Mo gbé, kò ní dáa fún ọ

iv. Ayé mi bàjẹ́, Dayọ̀, ò 'I am doomed; Dayọo, ń toast

v. Kò ní yẹ́ ọ́, orí ẹ burú

vi. Ọlọ́run ni yóò kọ ọ́; yóò kọ gbogbo ìdílé yín i. Tí mo bá purọ kí
'Let me be unfortunate in life if I am lying.'

'I am in trouble; this man has completely destroyed my life.'

'I am in trouble; It shall not be well with you.'

you are wooing a girl.'

'It shall not be well with you; you are doomed.'

'God will forsake you and your families.'
These èpè, as used in the selected films are not backed with magic, spell or supernatural forces, as such, they may not be effective. At times, some of the èpè used in the selected films are attached as appendage of éébú as italicized in the following examples:

4. i. Alápamáșișẹe, òkú olẹ, kò ní dáa fún o

ii. Olòșì ọ̣dọ́kọ, kò ní yẹ ọ, o ò ní jèrè

iii. Wèrè, kò ní dáa fún iyáláyàá e
'Lazy fellow; it shall not be well with you.'

'Destitute adulterer, it shall not be well with you.'

'Mad fellow; it shall not be well with your great grand mother.'
However, there are few cases in the selected Yorùbá films where èpè is used as an expression of pain; therefore, a solemn utterance is used with the intention to invoke a supernatural power to inflict punishment on someone as shown in Àpáàdì and Erù Arúgbó video films. In such cases, effigy was used to put such èpè on the offender(s). Such èpè may become effective immediately or may be dormant for some period depending on if the curser's vital energy goes into the èpè. Examples of such èpè is shown in (16) below. 
5.

i. Eyin ará Igbálá-ayé ! Awọ́n gbogbo oore ti mo șe yín poo, ibi lẹ fi sán fún mi. Ogun yóò jà yín. İgbóná, àsàsí kó máa bá gbogbo yín!

People of İgbálá-ayé! You pay me with evil for my good services to you all. Calamities will befall you.

At times, Èpè of this type may not be effective if the presumed offender is innocent of the offence he was accused of. That is what prompted the Yorùbá adage 'èpè ń rò kí ó tó jà ni'- 'a curse reflects before it attacks'.

\section{The Grammatical Analysis of Foul Language in Yorùbá}

In this section, we shall examine the language of èébú and èpè as used in the selected Yorùbá video films.

\section{The Language of èébú}

The daily socio-cultural evolutional phenomena in Yorùbá society favour a rich linguistic creativity for èébú. Although the special effect(s) that èébu have on the interlocutors depends not only on the linguistic structure of the language used. The usual approach to linguistic analysis of any utterance must examine the total meaning of the utterance before beginning any analysis. There are at least two kinds of meaning in the total meaning of an utterance. There are for example the meanings of the separate words as dictionary would record them (lexical meaning) and structural meanings (function words perform in an utterance). In light of this, the total linguistic meanings of èébu consist of the lexical meanings of each word used plus the structural meanings. However, we must state here that the borderline between the lexical meanings and the structural meanings of èébú is not always sharp and clear. Based on the linguistic characterization of èébú, we would like to show that the following constructions are prima facie evident: (a) phrases; (b) sentences.

\section{(A) Phrases}

The intermediate units between words and clauses are called phrases. Phrases do not normally constitute complete clauses. Phrases are named according to their clauses. These include verb phrase, noun phrase, adverbial phrase and preposition phrase. The most common phrase used in èébu is noun phrase. This may be due to the fact that èébú have to do with name-calling.

\section{The Noun Phrase (NP)}

The NP in Yorùbá language is a group of words that is headed by a Noun $(\mathrm{N})$ or Pronoun (P). The phrase got it name by virtue of the headedness. Yorùbá NP can be found in different constituents in the sentence; in the subject position, in the object position or as object of a preposition. Also, Yorùbá NP may vary in complexity. It may be simple to have contained an $\mathrm{N}$ or $\mathrm{P}$ only. It may contain a noun and it qualifier(s) as shown in (6) below:

6.
i. mo
"I"
ii. àwa
"we"
iii. ọmọ
"child"
iv. olè
"thief"
v. àwa Yorùbá
"we Yorùbas"
vi. ọmọ ọùnrin
"male child"
ọọ ayọkẹlléf funfun
"three white car"
vii. mẹta

As shown in (6) v-vii above, the qualifier(s) (as italicized) follows the noun it qualifies (Awóbùlúyì 1978:31). The noun it qualifies is usually referred to as the 'head' or 'head noun', (Bámgbóșé 1967:12; Yusuf 1997:8). Example (6vii) shows that a noun can have more than one qualifiers in the language. The complex NPs could be one with sentential qualifier(s) as in 
7.

ọmọ tí Olú nà "the child that Olu flogged"

Now, we shall examine èébú that are NPs in the selected Yorùbá video films

\section{Simple NPs}

The èébú used as simple NPs in the selected Yorùbá video films are in names which were either used with or without qualifiers. These include:

8.

\begin{tabular}{|c|c|c|c|c|}
\hline Adàgbàmádanú & 'daft person' & Afọ́jú & $\begin{array}{l}\text { 'blind } \\
\text { person' }\end{array}$ & $\begin{array}{l}\text { Syntax is not relevant to word } \\
\text { formation processes while }\end{array}$ \\
\hline Afọ́kungbému & 'fool' & Agùnmáníyè & $\begin{array}{l}\text { 'silly/ } \\
\text { stupid' }\end{array}$ & $\begin{array}{l}\text { morphology is not also relevant } \\
\text { to syntax. However, following }\end{array}$ \\
\hline Àjẹ́ & 'witch' & $\begin{array}{l}\text { Ajẹgborodàgbà } \\
\text { 'wanderer' }\end{array}$ & & Pulleyblank and Akinlabí(1988 \\
\hline Aláìnílàákàyé & 'moron' & Aláilójútì & 'shameless & the model below establishe \\
\hline Aláwòkù & 'daft' & Apọdà & 'fool' & the fact that morphology ar \\
\hline Arègòmu & 'drunkard' & Așệó & 'prostitute' & syntax interact. \\
\hline Dìndìnrìn & 'dense' & Ẹhànnà & $\begin{array}{l}\text { 'wild } \\
\text { person' }\end{array}$ & Morphology (1 and 2) \\
\hline Elẹ́dẹ & $\begin{array}{l}\text { 'pig' (dirty } \\
\text { person) }\end{array}$ & Ẹranko & 'animal' & 1 \\
\hline Erinmi & $\begin{array}{l}\text { 'hippopotamus' } \\
\text { (obese) }\end{array}$ & Ọ̀bùn & $\begin{array}{l}\text { 'dirty } \\
\text { person' }\end{array}$ & $\begin{array}{l}\text { Syntax } \\
\text { The model above sugges }\end{array}$ \\
\hline Ộợn-ọn & 'thief' & Òkóbó & $\begin{array}{l}\text { 'impotent } \\
\text { man' }\end{array}$ & $\begin{array}{l}\text { two morphological component } \\
\text { namely, morphology } 1 \text { an }\end{array}$ \\
\hline Olè & 'thief' & Ọlẹ & 'lazy person' & rnhology 2 This \\
\hline Ọlẹdàrùn & 'sluggard' & Olójúkòkòrò & $\begin{array}{l}\text { 'greedy/ } \\
\text { covetous' }\end{array}$ & exemplified as follows: \\
\hline Olóòrùn & ‘dirty person’ & Olóríburúkú & 'unfortunate & The word adé 'personal \\
\hline Onígbèsè & 'a debtor' & Òpònú & $\begin{array}{l}\text { person' } \\
\text { 'idiot' }\end{array}$ & name/ crown' is derived by \\
\hline Sọọọ̀dìyẹsà & 'imbecile’ & Wèrè & 'mad person' & prefix $\boldsymbol{a}$ to the verb $\boldsymbol{d} \boldsymbol{e}$ as give \\
\hline
\end{tabular}

With the exception of olè, ôfón-ọn dindinrin and wèrè, all other words above are formed in the language. In order to explain the formation process of these words, we shall employ the weak lexicalist hypothesis. The weak lexicalist hypothesis (WLH) states that some words are syntactically derived while others are not (Adeniyi 2007:36). The morphology and syntax constitute semiindependent, where the principle of the morphology govern categories of level $x^{1}$. No ordering is imposed between the components, hence, apart from the standard situation whereby the morphology provides inputs for the syntax, it is also possible for the syntax to derive a word category levels. The implication of the foregoing is that in the formation of words, both syntax and morphology interact as opposed to what Chomsky (1970) and others that believed that morphology and syntax are on different autonomies tiers. Syntax is not relevant to word ormation processes while to syntax. However, following Pulleyblank and Akinlabí(1988), model below establishes syntax interact.

A.

below:

9.

a + d é $\rightarrow$ adé
agent cover
Morphology 1

Other words formed in similar way in (8) above include

10.

$$
\begin{gathered}
\mathrm{a}+ \\
\text { adàgbàmádanú } \\
\text { di àgbà má da inú }]
\end{gathered} \rightarrow \begin{gathered}
\text { 'daft } \\
\text { person' }
\end{gathered}
$$




$$
\begin{aligned}
& \mathrm{a}+\text { [fọ̀ ikun gbé mu }] \rightarrow \quad \text { 'fool' } \\
& \text { afọ́kungbému } \\
& \mathrm{a}+\text { [Șẹ owó] } \rightarrow \text { așẹ́wó } \quad \text { 'prostitute' } \\
& \mathrm{a}+\text { [jẹ igboro da àgbà }] \rightarrow \quad \text { 'silly/ } \\
& \text { ajẹgborodàgbà stupid' } \\
& \text { à }+ \text { [jẹ] } \rightarrow \text { àjẹ́ } \quad \text { 'witch' } \\
& \text { ò }+ \text { [lẹ] } \rightarrow \text { ọlẹ } \quad \text { 'lazy } \\
& \text { ò }+ \text { [ponú] } \rightarrow \text { òpònú 'idiot' } \\
& \text { agent }+\mathrm{VP} \rightarrow \mathrm{NP}
\end{aligned}
$$

The derived word adé in (9) can functions as the subject of the sentence in (x).

11 .

$$
\text { (x) adé wá sí ilé ' ' adé came to the house.' }
$$

In (x), morphology is the input to the syntax as in $(\mathrm{y})$

(y) Morphology $1 \rightarrow$ Syntax (where words are put together to form a sentence). Similarly, we can also derive a word from the words/ lexical items in $(\mathrm{x})$ through the process called desententialization thus:

12.

$$
\begin{gathered}
\text { i. Adéwálé } \leftarrow \quad \text { Adé wa sí ilé 'Adé came home.' } \\
\text { ii. Ọ̀lẹdàrùn } \leftarrow \text { Ọ̀lẹ di àrùn } \begin{array}{l}
\text { 'laziness } \\
\text { becomes disease' } \\
\text { 'sluggard' }
\end{array}
\end{gathered}
$$

The above examples show that a sentence serves as the input to the word giving rise to morphology 2 as given in (z)

(B)

$$
\text { (z) Syntax } \rightarrow \text { Morphology }
$$

In the same vein, each of the following nouns extracted from (8) above

13.
i. eranko
'animal'
ii. erinmi
hippopotamus

is derived from a noun phrase thus:

14.
i. ẹranko $\leftarrow$
$[\mathrm{NP}[\mathrm{N}$ ẹran $]+[\mathrm{N}$ oko $]]$
ii. erinmi $\leftarrow$
$[\mathrm{NP}[\mathrm{N}$ erin $]+[\mathrm{N}$ omi $]]$

Where the noun phrases is the input of each of the word.

All of these examples, confirms the fact that a non-lexical category can derive a lexical one. Pulleyblank and Akinlabí (1988:158-160) say that the model in (A) above suggests that all morphological processes derivation (including phrasal derivation) and inflections are located

\begin{tabular}{|c|c|}
\hline i. Olórí gbọọrọ & 'long headed person' \\
\hline $\begin{array}{l}\text { ii. Olorí burúkú } \\
\text { talakanians }\end{array}$ & 'a wretched person' \\
\hline iii. Èyin ẹranko yìí & 'these animals' \\
\hline iv. Ọmọ òfò & $\begin{array}{l}\text { 'good for nothing } \\
\text { child' }\end{array}$ \\
\hline v. Ọmọ lásán èkejì ajá & 'useless child' \\
\hline vi. Àgbà ìyà & 'ignoble elder' \\
\hline vii. Wèrè dàgìnnìdọọrọ & 'a tall mad man' \\
\hline viii. Gbàdìgbagidi apá & $\begin{array}{l}\text { 'bulky and massive } \\
\text { arm' }\end{array}$ \\
\hline ix. Ọmọ àlè & 'bastard' \\
\hline x. Ọlọ́wọ ike & 'a sluggard' \\
\hline xi. Ọmọge adódòmáwẹ & 'a dirty lady' \\
\hline xii. Ọmọ ẹhannà & 'hooligan' \\
\hline xiii. Ọmọ rádaràda & 'a ruffian' \\
\hline xiv. Elẹ́nu irú & $\begin{array}{l}\text { 'stench-mouthed } \\
\text { person' }\end{array}$ \\
\hline xv. Epo pupa gààrí İsòbò & $\begin{array}{l}\text { 'a bad skinned } \\
\text { person' }\end{array}$ \\
\hline
\end{tabular}
within a single morphological component in which the syntactic input is needed in the formation of some words, the model is possibly modified to allow recursion from syntax into morphology.

We must add at this juncture that most of the words in (8) above are used metaphorically to give the addressee in the selected video films offensive names.

The nouns in example (8) above are used independently without qualifiers. However, there are other simple nouns with qualifier(s) used as èébú in the selected Yorùbá video films. These include the following:

15. 
The NPs used as èébú in example (15) above are used to describe the addressee in offensive manner. As in example (8) above, the NPs used in (15) above are also used metaphorically to either describe or name the addressee.

\section{The complex NPs}

The èébu that have complex NPs in the selected Yorùbá video films are of two types: (a) relatival NPs and (b) Simile NPs.

\section{(a) Relatival NPs}

This type of NPs contains a noun with relative clause qualifiers. The clause qualifier which typically begins with the relative particle tí marks sentences that are used as relative clause qualifiers, Awóbùlúyì (1978:94). The particle always appears at the beginning of sentences. For example: i. Ọmọ ọsàn tí ń kó póńpó bá iyá rẹ

ii. Ẹranko tí ó dașo ènìyàn bora

iii. Aláinnírònú tó ń bo ajá lợwó

iv. Ọ̀bùn ajímábọ́jú tó ń fojú àná wòran
'A troublesome child that brings problems to his parents'

'An animal in human skin'

'A fool that offers a dog handshake'

'A dirty-mannered person that lacks daily personal hygiene'
The utterances in (16) above are used metaphorically to describe referents' attitude in the selected Yorùbá video films.

\section{Noun Phrase (Simile)}

Simile is a linguistic expression used in overt comparison. It describes one object as being similar to another, Ọlátúnjí (1984:53). Simile is a form of meaning extension in which the sense of an expression is extended to another on the basis of resemblance. Simile is always marked by bí 'like' in Yorùbá language and bí in the language is a noun (Awóbùlúyì 1978:17;
Bámgbóșé 1990:100). All èébú that are used as simile in the selected video films are noun phrases in the language. The NP structure is however complex if it is derived from a sentence as shown in (17a) below.

$17 \mathrm{a}$.

\section{A B}

NP (SIMILE)

SENTENCE

i. İwọ kan bí odó ibílẹ — ìwọ kan tí o rí bí yìí $\leftarrow$ odó ibílẹ yìi

'You that look like local mortal (for pounding yam)'

ii. Ėyìn ẹ gànnàkù bí $\leftarrow$ ẹyìn rẹ̣ rí gànnàkù ijàpá $\quad$ bí ijàpá

'His back looks like that of tortoise'

iii. Elẹ́nu bí ẹnu àgé $\quad \leftarrow$ ẹnu rẹ rí bí ti àgé

'His mouth looks like that of rubber kettle'
iv. Àșán orí bí $\quad \leftarrow$ Ó șe kìkì orí bí ti tàgbìgbò agbìgbò

'A big headed person'

v. Ọkùnrin báńgẹ bí $\leftarrow$ Okùnrin tí ó rí ewédú $\quad \leftarrow$ bángẹ bí ewédú

'A light-weight man'

vi. Aláilójútì bí ẹja
konté

'A shameless person'

The complexity in each of the NP structure under $\mathbf{A}$ in (17a) above occurs because all words in each example are nouns in the language. However, the head noun of the NPs in (17a) is bí, without which the NPs becomes meaningless as shown in (17b) below.

$17 \mathrm{~b}$.
i. *ìọ kan odó ibílẹ yî́
ii. *ẹ̀ỳn ẹ̀ gànàkù ijàpá
iii. *àșán orí tàgbìgbò
iv. *ọkùnrin bángệ ewédú
v. * aláilójútì eja konté

However, if the NP structure is as shown in (18) below where the noun phrase (simile) occurs in the object position of a simple sentence, the complexity is removed.

(18)
i. Eyín ẹ fọ́ká bí iná wédà
'His teeth scattered
like welder's light' 

ii. Ó rí gbọọọ bí okùn șòkòtò
'He is tall like rope used to tie local trouser'
iii. Ọpọlọ yín yòrò $b i$ álợù
'Your brain dissolves like alum'
iv. Ó ń rìn bi àgàtú
v. Ẹnu ẹ nípọn bi ilẹkùn dánfó
'He walks like àgàtú (a farm labourer)'
'His lips are tick like dánfó (mini-bus) side door'

The head noun of the object noun phrase simile in (18) above is bí. The noun is followed by its qualifier(s) as italicized above.

\section{Sentences}

Having looked at èébú at the phrasal level, our focus here will be on the structure of èébú in sentence form in the selected Yorùbá video films. Sentence is the largest unit that shows grammatical patterning in a language. There are three types: simple sentence, the compound sentence and the complex sentence. Out of these types, simple sentence is used often in hurling insults in the selected Yorùbá video films. The reason for this may not be far fetched. The use of simple sentence by the insulter to hurl insults on the addressee, we assume, will allow the insulter to hit the nail on the head in order for the insults to have a great effect on the perlocutor.

The simple sentence is a one clause sentence which consists of NP subject and a predicate thereby making it easy to grasp. Simple sentences which come up in diverse structures are common in our day to day conversations, Yusuf (1997:59). It may come in form of declarative or imperative statements. Sometimes, they are employed as questions. Similarly, èébú in sentence form in the selected Yorùbá video films contains one verb and specify a single event. It however comes in the following different forms:

\section{(a) Declarative}

This type is used in the expression of statements. For example
19.
i. O gọ
'You are stupid'
ii. Inú yín bu
'You are daft'
iii. Kọ́kọ́rọ́ orí ẹ sọnù
'You have lost your senses'
iv. Ó ń ranjú fòò
'He is mopping'
v. Ó rí bí igi ị̀áná
'He is too skinny'

\section{(b) Interrogative}

These are èébú that are employed as questions. For example

20.
i. Ojú ẹ fọ́ ni?
'Are you blind?'
ii. Șé o ò yọnu?
'Are you mentally balanced?
iii. Kí ló șe olóòórùn yìí ná?
'What is wrong with this stench?
iv. E ò nírònú ni?
'Are you daft?'

In most cases where èébú in interrogative sentences are used, they are not used to seek information; rather, they are used rhetorically to express anger, impatience or disgust. However, in some cases in the selected Yorùbá video films, we observed that the addressee may answer such questions in order to be rude especially, if he is not a subordinate to the insulter as in the dialogue below.

21.
A. Kí ni were ẹ ń wá
'What is this idiot níbí? searching for here?
B. Asínwín ẹ náà ni mò 'It's you fool I am ń wá! searching for!'

\section{(c) Negative}

This type of sentences contains at least one negative word. The common negative word in èébú is kò, which also occurs as ò, ẹ in the following examples:

22.
i. kò gbádùn ni
'He is sick'
ii. Omọ tí ò níbi-níran
'A child without good family background' 

iii. Orí ẹ ò pé
'You are stupid'
iv. E ò ní làákàyè
'A dullard'
v. Ẹ ẹ Ṣ̀nìyàn
'You lack manners'

\section{(d) Code-mixing}

Code-mixing is a phenomenon common in bilingual speech communities in which the speakers of the two languages in question transfer linguistic elements from one language into another. The speaker combines lexical items and features of both languages in a single discourse. Such mixed forms are found in èébú in the selected Yorùbá video films as shown in (23) below.

23.
i. Oppọlọ ẹ ti kó virus
'Your brain is malfunctioning'
ii. Compound illiterate 'You are a compound ni ẹ́ illiterate'
iii. Olóòrùn tó ń lo black 'A dirty lady that bra uses black bra'
iv. First class lo wà nínú 'Your deafness is àwọn adití first class'
v. Òpákan, o stupid 'Òpákan, you are stupid'

\section{The Language of èpè}

Unlike èébú which comes up in noun phrase and sentences, èpè comes in verb phrase and sentences.

\section{The Yorùbá Verb Phrase}

Traditionally, the verb phrase is a group of words that has the sentence predicator, namely, the verb, Yusuf (1997:21). The main verb is the head of the verb phrase, Lamidi (2000:80). As the head of the verb phrase, the verb is obligatorily present in Yorùbá with or without its satellites (complements), Awóbùlúyì (2013:98-99). The verb phrase complements in Yorùbá could have NP complements or sentential complements, Yusuf (1997:31). Adverbs may occur in Yorùbá verb phrase. Whenever they occur, they modify the verb in the verb phrase. Two types of adverbs occur in a verb phrase: those that occur before verbs and are therefore referred to as preverbal adverbs, and those that occur after verbs which are consequently referred to as post-verbal adverbs, Awóbùlúyì (2013:142-143). In èpè, only preverbal adverbs kò níí occurs mainly in the verb phrase as shown in example (24) below.

24.
i. kò níí yẹ ọ́
'It shall not be well with you'
ii. kò níi dáá fún ìyá ẹ 'It shall not be well with your mother'
iii. kò níí rí bátiṣe
'You shall not make it in life'
iv. kò níi dára fún ọ
'It shall not be well with you'

The adverbs kò níi in the verb phrase above marks the future tense in the negative.

\section{Sentences}

Like èébú, simple sentences are used in èpè. The simple sentences however come in the following forms:

\section{(a) Declarative}

This type expresses a fact in the affirmative, negative or futuristic.

\section{Affirmative}

25.

$\begin{array}{lll}\text { i. } & \text { Mo gbé. } & \text { 'I am in trouble' } \\ \text { ii } & \text { Ayé mi bàjẹ.. } & \text { 'I am doomed' } \\ \text { iii. } & \text { Iná jó mi. } & \text { 'I am doomed' } \\ \text { iv. } & \text { Mo dáràn. } & \text { 'I am in soup' } \\ \text { v. } & \text { Orí ẹ ti burú. } & \text { 'Your life is ruined' }\end{array}$

\section{Negative}

26.

i. E ò lè șoríire 'It shall not be well with you'

ii. O ò lè ráláànú 'Helpers shall be far from you' 
iii. Orí ẹ ò pé 'You are insane'

The negation marker is ò 'not' in example (26) above.

\section{Futuristic}

This type of sentences is signified by the presence of any one of yóò/óò, ó máa 'will/shall' as shown in the following examples.

27.

i. Ẹ̀mí ẹ ló máa bọ́
ii. Ògún ló máa pa ẹ

'You shall die'

'You shall be struck by Ògún (god of iron in Yorùbá land)

iii. $\quad$ Ọộrún ni yóò kọ ọ́

'God shall forsake you'

iv. $\quad$ Ayé ẹ máa bàjẹ́

'Your life shall be ruined'

v. Ẹ óò parun

'You shall be destroyed'

vi. E E óò kú sọnà bí èéfín 'You shall faint on the way like smoke.'

Likewise, in negative sentences containing (k)ò, future action is signified by níi 'shall'. For example:

28.

$\begin{array}{lll}\text { i. } & \text { E ò níí délé } & \begin{array}{l}\text { 'You shall not get to } \\ \text { your destination' }\end{array} \\ \text { ii. } & \begin{array}{l}\text { Ayé ìyáláyàá ẹ ò níí } \\ \text { dáa }\end{array} & \begin{array}{l}\text { 'Your grandmother } \\ \text { shall be unfortunate' } \\ \text { 'You shall not make } \\ \text { it' }\end{array} \\ \text { iii. } & \text { E ò níi jèrè } & \begin{array}{l}\text { 'You shall be } \\ \text { unfortunate in life' }\end{array} \\ \text { iv. } & \text { O ò níí șoríire } & \end{array}$

\section{Interrogative}

These types of èpè are employed as questions. For example

29.
i. Ayé yín fẹ́ bàjẹe ni?
'Are your lives destroyed?'
ii. Sé orí yín ò burú?
'Do you want to be doomed?'
iii. E E gbèpè ni?
'Are you cursed?'
iv. Àbí ayé yín fẹ́ rún 'Are your lives ni? ruined?'

Depending on the status of the curser to the addressee, such question may not necessarily require an answer.

\section{Conditional}

This type of sentences is complex and is introduced by tí 'that'or bí 'if', in the language. The èpè that comes in this form are always in two parts. One part is the sentence itself (condition for the curse to be effective) and the other is the actual curse. For example

30.

i. 'Ojọ̣ kọj jọ tí o bá fi ọmọ mi Bímpé sílẹ̣, o ó Șòfò ẹmí, o ó șòfò ohun gbogbo'.

'Any day you divorce my daughter Bimpe, you shall lose your life and all you have.'

ii. 'Àwọn tó ń sọ̀rọ mi láìda lẹyìn, bí wọ́n bá fojú ọwọ șișẹ́, wọn óò fẹ̀yìn ọwọ́ dàá nù'

'Those that back bite me shall not be profitable in their doings.'

iii. 'Bí mo bá purọ mọ ẹ, kí ìyá mi șòfò mi'

'Let my mother lose me if I lied against you'

iv. 'Bí ó bá fún mi lówó, kí n má jèrè'

'Let me not be profitable if he gave me money.'

\section{Conclusion}

So far in this study, we have been able to show that èébú and èpè are not Yorùbá oral genres but rather, they are forms of expression used to express one's emotion: hatred, aggression and anger to the people. This use of èébú and èpè is known and common in the speech of the people that it is now becoming regular language in a simple daily conversation in the society and in the selected Yorùbá video films. Unlike èébú which is frequently used èpè is seldom used because it is believed that it may be backed by supernatural forces. Also, in this study, we have appraised the structural components of èébú and èpè. We observed that most word used as èébú are formed in the language and are used metaphorically with 
or without qualifiers. Also the sentences used for èébú and èpè often come in simple sentences to allow the addressee grasp the meaning in such that its impact will be greatly felt.

DStv is a pay digital satellite TV service in Africa. It is founded by Multichoice in 1995. Its headquarters is located at Fernadale Randburg, South Africa.

\section{References}

Adébọwálé, O. \& Olumuyiwa, T. (Forthcoming) 'Sexualized Language in Juju Music: An Examination of Saint Janet Music'.

Adéníyì, H. 2007. 'A Morphology of Edo.' Doctoral Dissertation, Univerity of Ibadan.

Agyekum, K. 2004. "Inventive Language in Contemporary Ghanian Politics." Journal of Language and Politics. 3:2, pp.345-375.

Awóbùlúyì, O. 1978. Essentials of Yorùbá Grammar. Ibadan: Oxford University Press.

Awóbùlúyì, O. 2013. Ė kọ Gírámà Ėdè Yorùbá. Oșogbo: Atman Limited.

Babou, M. 2014 “ A Sociolinguistic analysis of use and Perception of insult: Tlemcen Speech Community." International Journal of Academic Research and Reflection volume 2, no 4, pp. 110-120.

Bámgbóșe, A. 1967. A Short Yorùbá Grammar.Ibadan: Heinemann Educational Books (Nigeria) Ltd.

Bámgbóșe, A. 1990. Fonọ́lọjì ati Gírámà Yorùbá. Ibadan: University Press PLC

Chomsky, N. 1970. 'Remarks on Nominalization' in R. Jacobs \& P. Rosenbaun (eds.) Readings in English Transformational Grammar. Ginn,Walthem (MA), Ginn 184-221.

Copi, I. M. 1953. Introduction to Logic. London: The Macmillan Company.

Ekwuazi, H, Sokomba. J. and Mgbejume, O. (eds). 2001. Making The Transition From Video to Celluloid. NFI: National Film Institute.

Fielder, J. 2007. How to deal with Insults. New York: The Rosen Publishing Group.

Fine, G. A. 1981. "Rude Words, Insults and narration in Preadolescent Obscene talk." Maledicta V, pp. 51-68.

Finegan, E. 2004. Language: Its structure and use. Thomson Wadsworth.

Fodor, J. D. 1982. Semantics: Theories of meaning in Generative Grammar. Brihton, Sussex: The Harvester Press Limited.

Gabriel, Y. 1998. “An Introduction to Social Psychology of Insults in Organizations.” Human Relations 51 (1):1329-1354.

Juker, Andreas. 2000. "Slanders, Slurs and Insults on the Road to Canterbury: Forms of Verbal aggression to Chancers Canterbury Fales" in placing Middle English in Context. Taavitsainen I, Nevalainen T, Pahta P and Rissanan, M. (eds) pps 369- 390 Berlin: Mouton de Grayter.

Kluckhohn, C. 1949. Mirror for Man. Mc Graw-Hill Book Co., Inc.

Lamidi, M. T. 2000. Aspect of Chomskyan Grammar. Ibadan: Emman Publications.

Leech, G. 1983. Principles of Pragmatics. London: Longman.

Mateo, J. \& Yus, F. 2013. "Towards a cross-cultural Pragmatic Tokonomy of Insults within the communicative act of insulting." Journal of Language Aggression and Conflict 1:1, pp. 89- John Benjamins Publishing Company.

McGregor, M. B. 2009. Linguistics: An Introduction. Continuum International Publishing Group. London. 
Mcphee, N. 1978. The Book of Insults: Ancient and Modern. Fatura Book. Camberwell, London.

Mgbejume, O. 2006. 'Movie Stories: The Surgical Cure for Emotional Problems'. Beyond the Screen A Journal of the National Film Institute Vol. no 1, pp. 36-42.

Olatunji, O.O. 1984. Features of Yorùbá Oral Poetry. Ibadan: University Press.

Olutoye, O. 1987. 'Ipò èébú Nínú Lítítéṣọ Yorùbá' Paper read at Seminar in memory of Kárunwí, University of Lagos, September 24-26, 1987.

Opệfẹyìntìmí, A. 2010. İtúpalè Èpè. Ilé-Ifẹ: Obafemi Awolowo University, Press.

Pulleyblank, D. \& Akinlabi, A. 1988. 'Phrasal Morphology in Yorùbá' Lingua 74: 141- 166.

Yai, O.B. 1975. 'Oral Literature Among theYoruba- Speaking people of Central Dahomey in Yorùbá' in Yorùbá Oral Tradition. Abimbola. W (ed.) Ilé-Ifẹ̀: Department of African Languages and Literatures, University of Ifẹ.. Pp. 599- 629.

Yusuf, O. 1997. Transformational Generative Grammar: An Introduction. Ijebuode: Sebotimo Publications.

\section{Videography}

Abẹrẹe. Tokunbọ Ọláộẹé, 2013, Zentury Pictures.

Abúlé Mecho. Bọ́lájí Amúsán, 2012, Mr. Latin film productions.

À̀ná Òrósùn. Afọnjá Ọlániyì, 2010, Almaroof Standard Investment Ltd.

Alákadá. Toyin Aimakhu, 2009, Epsalum Movie productions.

Àpáàdì. Fúnkẹ́ Akíndélé, 2012, Olasco Films Productions.

Bánkàrere. T.A.A Ladélé, 2012, Glamour Films \& Records Nig. Ltd.

Dókità Ige. Tajudeen Ọla Abdulah, 2011 Jim-Tworld of Entertainment.

Ètekéte. Wilson Olusegun Bismak, 2011, Corporate Pictures.

Erù Arúgbó. Adéọlá Shorẹmí, 2013, Sir White Media Network.

İbéèrè. Sunny Ali, 2012, Afeezco Films International Ltd.

İbinú Ờrúnmilà. Peter Fatomilọla, 2013, Prime Pictures Ltd.

Ilá Alásèpọ. Iníolúwa Odẹbọdé, 2014, Corporate Pictures.

Ilé Aláyọ. Fẹmi Adébáyọ, 2012, ZAinab Ventures International Limited.

Ináwó. Saheed Akangbé 2013, Jim-Tworld of Entertainment.

İyá ọbámà. Tẹnílá Bello, 2013, Ewéńlá Films \& Records International.

Iyàwó Elẹnu Razor. Mustapha Bakry, 2006, Adé -Mike films Productions

Jéjẹlóyẹ. Toyin Aimakhu, 2012, Tenten Pictures Ltd.

Màmá Insurance, 2012. Liz Da-Silva, Epsalum production

Odídẹeẹ. Fẹmi Fadèyí, 2006, Remdel Optimum Communications.

Oko Obinrin. Mosunmọ́lá Filàní, 2011, Gemini Films \& Marketing Ltd.

Oko Mama ẹ. Odúnladé Adékọlá, 2012, Gemini Films \& Marketing Ltd.

Omo Elẹmẹsọ́. Yéwándé Adésànyà, 2013, Olasco Films Productions.

Orẹ mẹta Wèrè kan. Tayọ Amọ́kadé, 2014, YetQueen Films Productons.

Osas. Mercy Aìgbè, 2012, Lawlar His Grace Nig. Ltd.

Pele Modina. Olaniyi Afọja, 2013, Adekaz Productions Ltd.

Suzzy Mama. Yewande Wùmí, 2013, Corporate Pictures.

Teacher Oko. Ọlániyì Afọnjá, 2013, Small world Productions Nig. Ltd. 
Tẹnbẹlú. İyábọ Òjó, 2014, Corporate Pictures

Ti Olúwa ló nilẹ. Tunde Kilani, 1995, MainFrame Film \& Television Productions.

Wazo. Funke Akindele, 2014, Olasco Films Nig. Ltd.

\title{
Лингвистическая оценка ненормативной лексики в избранных телевизионных фильмах Йорубы
}

\author{
Темитопе Олумийива \\ Университет Адакунле Аджасин \\ Акунгба-Акоко, Нигерия
}

\begin{abstract}
Представляя собой сложный человеческий феномен, язык используется для неформального, экспрессивного общения и указаний. Окружающий мир, в котором мы живем, является в значительной степени вербальным, в этой связи язык выполняет экспрессивную функциию, когда используется в общении для того, чтобы добиться большей эффективности и вежливости от людей, а также провоцирует или нивелирует социиальные проблемы. Для создания социального напряжения обычно используется ненормативная лексика. Структуры ненормативной лексики, встречающиеся в повседневной жизни народа Йоруба, отражены в телевизионных фильмах. Это ещее раз подтверждает общепризнанное мнение, что фильмы являются отражением того, что происходит в обществе. Использование ненормативной лексики в телевизионных фильмах Йорубы стало обычным явлением, которому не придается особого значения. В данной статье исследованы два вида ненормативной лексики: оскорбления (е́е́bú) $u$ проклятия (ѐрѐ). Таким образом, основной задачей данной работы является лингвистическая оценка двух видов ненормативной лексики, используемой в телевизионных фильмах народа Йоруба. В статье рассматривается социально-семантический подтекст ненормативной лексики, используемой в телевизионных фильмах, и показано, что оскорбления встречаются в фильмах чаще, чем проклятия. Кроме того, проведен грамматический анализ ненормативной лексики, отмеченной в избранных телевизионных фильмах. Выявлено, что оскорбления чаще всего встречаются в виде именных словосочетаний и предложений, в то время как проклятия представляют собой глагольные словосочетания и предложения. Предложения, используемые в обоих случаях, являются простыми, состоящими из подлежащего, представленного именным словосочетанием, и сказуемого, что позволяет легко понять смысл предложения.
\end{abstract}

Ключевые слова: Йоруба, телевизионный фильм, именное словосочетание, глагольное словосочетание, оскорбления (ѐе́bú), проклятия (ѐрѐ).

Научная специальность: 22.00.00 - сочиологические науки, 23.00.00-политология. 